\title{
PENGARUH INCOME, DEBT, GENDER DIFFERENCES, FINANCIAL LITERACY, DAN FINANCIAL ATTITUDE TERHADAP FINANCIAL SATISFACTION
}

\author{
Ucik Nurul Hidayati Siswoyo \\ Universitas Negeri Surabaya \\ uciksiswoyo@gmail.com \\ Nadia Asandimitra \\ Universitas Negeri Surabaya \\ nadiaharyono@unesa.ac.id
}

\begin{abstract}
This study examines the financial satisfaction among the employees in the District of Sidoarjo and analyses the relationship between income, debt, gender differences, financial literacy, and financial attitude. The object of this research is the employees in the District of Sidoarjo and data collection techniques using purposive sampling and snowball sampling. The total number of respondents obtained is 298 by distributing questionnaires online. This research is conclusive causality and uses Structural Equation Modeling (SEM) analysis technique in AMOS software version 24. This study showed that debt and financial attitude significantly affect financial satisfaction. In contrast, the variable income, gender differences, and financial literacy does not affect financial satisfaction. This study can be a valuable reference for various parties, especially employees, where you should always act and behave better in economic terms because the attitude towards finance plays a vital role in determining the success or failure of the financial behaviour of individuals. The high perspective of the individual financial can evaluate the heightened awareness in responsible for the expenditure of finances, so it will cause a positive impact on the behaviour of financial management to achieve the satisfaction of personal finance.
\end{abstract}

Keywords: debt; financial attitude; financial literacy; gender differences; income.

\section{PENDAHULUAN}

Hasil sensus ekonomi 2016, lapangan usaha perdagangan baik mikro ataupun besar menjadi penyerap pekerja terbanyak yaitu 22,37 juta orang $(31,81 \%)$ dari sejumlah tenaga kerja di Indonesia. Lapangan usaha industri pengolahan berada pada peringkat kedua setelah perdagangan eceran maupun besar, di mana serapan pekerja sebesar 15,99 juta orang $(22,75 \%$ ), sedangkan peringkat ketiga yaitu usaha penyedia minuman, makanan, serta penyedia akomodasi dengan tingkat penyerapan tenaga kerja sebesar 8,41 juta orang $(11,97 \%)$ dari total pekerja (Wijanarka et al., 2018). Menurut Wijanarka et al.(2018), Pulau Jawa menjadi daerah dengan mayoritas usaha/perusahaan terbesar di antara pulau lain di Indonesia yaitu sebesar 16,2 juta usaha/perusahaan atau setara dengan 60,74\%.

Sektor produksi menjadi salah satu sektor yang sangat bergantung kepada pertumbuhan ekonomi. Sektor ini akan membutuhkan tenaga kerja sebagai modal utama dalam menggerakkan operasional perusahaan. Penduduk bekerja yang sesuai dengan status pekerjaan utama terdiri dari buruh/karyawan/pegawai, kemudian ada penduduk yang bekerja dengan berusaha sendiri, penduduk yang berusaha dengan dibantu karyawan tidak tetap, berusaha dibantu karyawan tetap, tenaga kerja keluarga yang dibayar, tenaga kerja bebas pada sektor pertanian, maupun tenaga kerja bebas pada sektor non-pertanian (Wijanarka et al., 2018).

Upah/gaji merupakan hak para pekerja yang diterima dan dinyatakan dalam bentuk uang sebagai imbalan yang diberikan oleh pengusaha atau pemberi kerja kepada pekerja. UMP tertinggi di Indonesia yaitu sebesar Rp4.416.186,548 yang dimiliki oleh Daerah Khusus Ibu Kota Jakarta. Sementara itu Jawa Timur adalah salah satu provinsi yang memiliki nilai UMP tertinggi di Pulau Jawa yang berada di urutan ke tiga dibandingan lima provinsi lainnya. Upah Minimum Provinsi Daerah Khusus Ibukota Jakarta sejumlah Rp4.416.186,548, Banten dengan UMP sejumlah Rp2.460.996,54, Jawa Timur sejumlah Rp1.868.777,08, Jawa Barat sebesar Rp1.810.351,36, Jawa Tengah sebesar Rp1.798.979,00, dan 
Ucik Nurul Hidayati Siswoyo \& Nadia Asandimitra. Pengaruh Income, Debt, Gender Differences, Financial Literacy, dan Financial Attitude terhadap Financial Satisfaction

tingkat UMP terendah di Pulau Jawa adalah Rp1.765.000,00 untuk Daerah Istimewa Yogyakarta (Rizal, 2021).

Jawa Timur termasuk provinsi yang memiliki tingkat UMP tertinggi di Pulau Jawa, yang berada pada tingkat ketiga setelah DKI Jakarta dan Banten (Rizal, 2021). Kabupaten Sidoarjo juga menempati peringkat ketiga dalam daftar UMK Jatim setelah Kota Surabaya dan Kabupaten Gresik. Maka dari itu, dengan tingkat UMK yang berkategori tinggi tersebut, seorang buruh/karyawan/pegawai di Kabupaten Sidoarjo diasumsikan dapat melakukan pengelolaan finanasialnya dengan baik guna mencapai kepuasan keuangan secara pribadi (Septiana, 2021).

Financial satisfaction merupakan kondisi puas seseorang dengan keuangan yang telah dimilikinya, ketika suatu insan dapat melakukan pemenuhan kebutuhan hidup bersama uang yang dipunyai (Hasibuan et al., 2018). Terdapat banyak variabel yang dapat memberikan pengaruh terhadap financial satisfaction. Nugraha et al., (2020) mengemukakan bahwasanya income dan financial literacy memiliki pengaruh positif pada financial satisfaction. Long et al. (2016) menunjukkan debt berpengaruh terhadap financial satisfaction. Menurut Sina (2013), gender differences berpengaruh terhadap financial satisfaction, sedangkan Darmawan \& Pamungkas (2019) menyebutkan financial attitude memiliki pengaruh positif pada financial satisfaction.

Faktor pertama yang memengaruhi financial satisfaction adalah income (Candra \& Memarista, 2015; Aboagye \& Jung, 2018; Yulianingrum et al., 2021; Nugraha et al., 2020). Income merupakan suatu penghasilan yang didapatkan atas suatu terhadap masa yang telah ditentukan yang kemudian dipergunakan sebagai pemenuhan yang dibutuhkan pada hidupnya (Candra \& Memarista, 2015). Wahab et al., (2019) memperlihatkan bahwa semakin tinggi penghasilan maka bisa bertambah besar peluang untuk mencapai rasa puas finansial. Hasil penelitian tersebut memiliki persamaan dengan penelitian Candra \& Memarista (2015), Aboagye \& Jung (2018), Yulianingrum et al., (2021), dan (Nugraha et al., 2020). Namun, Amelia \& Isbanah (2021) dan (Rusdini, 2021) menyebutkan income tidak memiliki pengaruh terhadap financial satisfaction.

Faktor berikutnya adalah $d e b t$, di mana hutang merupakan tanggungan berupa kewajiban kepada pihak lain yang bersangkutan untuk diselesaikan (Rusdini, 2021). Aboagye \& Jung (2018) dan Long et al., (2016) mengemukakan bahwa debt berpengaruh pada financial satisfaction. Hasilnya tidak sejalan dengan Rusdini (2021) yang tidak dapat membuktikan pengaruh debt terhadap financial satisfaction karena keputusan seseorang untuk berhutang tidak selalu dilatarbelakangi oleh rasa kekhawatiran akan kondisi keuangan.

Faktor ketiga adalah gender differences, di mana gender differences dapat diartikan sebagai yang membedakan berdasar biologis di antara perempuan juga laki-laki yang ada dari lahir (Sina, 2013). Jenis kelamin merupakan karakteristik yang membedakan cara berperilaku antara laki-laki dan perempuan (Sina, 2013). Penelitian yang dilakukan oleh Sina (2013) gender differences berpengaruh yang signifikan pada financial satisfaction. Hasilnya tidak sejalan dengan Wahab et al., (2019) di mana gender differences tidak berpengaruh secara parsial terhadap financial satisfaction.

Faktor keempat yaitu financial literacy. Menurut Prabowo \& Asandimitra (2021), financial literacy adalah kompetensi individu ketika menentukan sebuah putusan finansial sesuai tujuan kemudian bisa mengindarkan individu dari pengambilan keputusan yang salah. Yulinar et al. (2020) menunjukkan financial literacy memiliki pengaruh signifikan positif teharap financial satisfaction. Hasil tersebut sesuai dengan penelitian Prabowo \& Asandimitra (2021), Candra \& Memarista (2015), Adiputra (2021), dan Nugraha et al., (2020). Tetapi hasil penelitian tersebut tidak sejalan dengan penelitian Amelia \& Isbanah (2021), Mukhafi (2020), Rusdini (2021), dan Yap et al. (2018) yaitu tidak terdapat pengaruh antara financial literacy pada financial satisfaction.

Faktor terakhir dalam penelitian ini yaitu financial attitude. Menurut Darmawan \& Pamungkas (2019), financial attitude merupakan keadaan pola pikir individu dalam menunjukkan setuju atau tidaknya 
individu dalam bidang keungan. Menurut Adiputra (2021), financial attitude berpengaruh signifikan positif terhadap financial satisfaction. Hasil ini sesuai dengan Darmawan \& Pamungkas (2019) dan Candra \& Memarista (2015), namun berbeda dengan Mukhafi (2020), Prabowo \& Asandimitra (2021), dan Yap et al., (2018) yang menyebutkan financial attitude tidak memiliki pengaruh pada financial satisfaction. Tujuan penelitian ini menganalisis pengaruh income, debt, gender differences, financial literacy, dan financial attitude terhadap financial satisfaction pada karyawan.

\section{KAJIAN PUSTAKA DAN PENGEMBANGAN HIPOTESIS}

\section{Subjective Wel-Being Theory}

Menurut Diener et al. (2003), Subjective Well-Being Theory (SWB) merupakan teori yang menghubungkan perasaan puas individu dengan pengukuran kualitas hidup. Subjective Well-Being Theory $(S W B)$ memberikan penjelasan bahwasanya individu bisa mengevaluasi diri mencakup reaksi emosionalitas pada suatu peristiwa, kondisi hati, juga pemberian nilai pada tingkah laku yang sudah dikerjakan yang berhubungan bersama pemenuan juga kepuasan. Perasaan senang dan tidak senang yang dialami seseorang berhubungan dengan tingkat kepuasannya, jika seseorang banyak merasakan kesenangan dalam hidupnya maka akan mudah mencapai kepuasan dan sebaliknya. Diketahui bahwa seseorang dapat mencapai tingkat kepuasannya tersebut bergantung pada kegiatan emosionalitas yang telah dialami (Diener et al., 2003). SWB di dalam penelitian ini digunakan sebagai teori yang mampu menjelaskan variabel financial satisfaction, income, debt, dan gender differences.

\section{Theory of Planned Behavior}

Menurut Ajzen (2002), Theory of Planned Behavior (TPB) yaitu teori yang mempelajari tentang studi terkait perilaku seseorang. Faktor utama yang menjadi dasar seseorang dalam berperilaku adalah niat, seseorang akan berkeinginan untuk melakukan beberapa hal karena memiliki maksud dan tujuan tertentu. Terdapat tiga jenis pertimbangan dalam berperilaku yang dimuat pada teori ini, yaitu attitudes toward behavior, subjective norms, dan perceived behavioral control (Ajzen, 1991). Theory of Planned Behavior (TPB) di dalam penelitian ini digunakan sebagai teori yang mampu menjelaskan variabel financial attitude dan financial literacy.

\section{Financial Satisfaction}

Financial satisfaction (kepuasan keuangan) merupakan perasaan puas seseorang yang dapat dipengaruhi oleh faktor kondisi keuangannya (Candra \& Memarista, 2015). Seseorang yang memiliki keadaan finansial dengan baik diasumsikan dapat melakukan pemenuhan yang dibutuhkan hidup bersama finansial yang dipunyai. Jika yang dibutuhkan dalam kehidupan telah terpenuhi, maka kepuasan seseorang dapat tercapai (Nugraha et al., 2020). Berdasarkan penelitian Hasibuan et al. (2018), kepuasan keuangan seseorang bisa dilakukan pengukuran dengan mempergunakan sejumlah parameter yakni tabungan, pinjaman, pemenuhan terhadap yang dibutuhkan secara mendasar, penghasilan, penentuan tujuan hidup, ketersediaan uang untuk masa yang akan datang, dan pengelolaan keuangan.

\section{Income}

Menurut Sawitri (2018), income memiliki definisi yaitu perihal yang didapatkan suatu insan baik berbentuk keuntungan, penghasilan yang didapatkan, ataupun penghasilan lain-lain. Kebutuhan hidup dapat terpenuhi dengan semakin tingginya tingkat pendapatan, jika hal ini terjadi maka seseorang akan mampu mencapai tingkat kebahagiaannya (Candra \& Memarista, 2015). Menurut Safryani et al. (2020), meperlihatkan bahwasanya parameter yang mampu dipergunakan untuk melakukan pengukuran variabel income adalah gaji/ upah dan bonus/ komisi.

\section{Debt}

Debt dapat didefinisikan sebagai yang diwajibkan pada finansial terhadap pihak lainnya yang belum terlunasi, hutangnya yakni asal modal maupun dana atau modal melalui sumber dari pemberi pinjaman (Rusdini et al., 2020). Menurut Sahi (2013), parameter yang mampu dipergunakan menjadi tolak ukur adalah kemampuan untuk tidak berhutang, jumlah hutang, kemampuan dalam membayar hutang, 
Ucik Nurul Hidayati Siswoyo \& Nadia Asandimitra. Pengaruh Income, Debt, Gender Differences, Financial Literacy, dan Financial Attitude terhadap Financial Satisfaction

kemampuan pemenuhan kebutuhan darurat, tabungan, gaya hidup, kecukupan uang yang dimiliki, ketersediaan uang untuk masa depan, dan perencanaan ketika telah pensiun.

\section{Gender Differences}

Gender differences merupakan yang membedakan diantara perempuan beserta laki-laki dalam aspek biologisnya yang telah ada sejak manusia dilahirkan (Sina, 2013). Faktor pembeda antara laki-laki dan perempuan terletak pada manajemen keuangannya. Artinya semakin bagus pengelolaan keuangan, maka akan semakin besar peluang untuk mencapai kebebasan keuangan (Sina, 2013). Parameter yang bisa dipergunakan untuk melakukan pengukuran variabel gender differences pada riset Handi \& Mahastanti (2012) yaitu evaluasi, kecemasan, serta tidak dermawan.

\section{Financial Literacy}

Financial literacy yaitu sebuah sikap positif seseorang dalam membuat suatu keputusan finansial dengan memanfaatkan pengetahuan yang dimiliki (Nugraha et al., 2020). Financial literacy bisa memberikan pengaruh pemikiran suatu insan terhadap pengelolaan keuangannya. Dengan pemikiran dan pengelolaan finansial dengan baik, jadi kepuasan keuangan suatu insan bisa tercapai dengan mudah (Candra \& Memarista, 2015). Chen \& Volpe (1998) menjelaskan bahwa financial literacy diukur dengan empat parameter yakni pinjaman juga simpanan, investasi, asuransi, beserta pengelolaan keuangan pribadi.

\section{Financial Attitude}

Financial attitude merupakan suatu tindakan seseorang dalam menghadapi masalah keuangannya, tindakan tersebut dapat digambarkan dengan berbagai reaksi berupa sikap positif ataupun negatif yang berbeda pada setiap individu (Rai et al., 2019). Menurut Prabowo \& Asandimitra (2021), financial attitude berperan penting untuk menentukan keberhasilan atau kegagalan perilaku keuangan individu. Herdjiono \& Damanik (2016) mengungkapkan bahwa variabel financial attitude dapat diukur menggunakan enam indikator antara lain obsesi, kekuatan, usaha, ketidakcukupan, penyimpanan, serta keamanan.

\section{Pengaruh antar Variabel}

Pengaruh income terhadap financial satisfaction dalam penelitian ini dapat dijelaskan berdasarkan subjective well-being theory (Amelia \& Isbanah, 2021). Income menjadi salah satu faktor penentu seseorang untuk mencapai kepuasan keuangan, di mana semakin tinggi pendapatan maka akan semakin besar peluang seseorang untuk mencapai kepuasan keuangan (Wahab et al., 2019). Sama halnya dengan penelitian yang dilakukan oleh Candra \& Memarista (2015); Yulianingrum et al., (2021); Aboagye \& Jung (2018); dan Nugraha et al., (2020). Namun penelitian Amelia \& Isbanah (2021) dan Rusdini (2021) menunjukkan hasil yang berbeda, di mana income tidak berpengaruh terhadap financial satisfaction.

\section{H1: Income berpengaruh terhadap financial satisfaction pada karyawan.}

Pengaruh debt terhadap financial sastisfaction dalam penelitian ini dapat dijelaskan berdasarkan subjective well-being theory (Rusdini, 2021). Seseorang yang berhutang tentunya harus mengetahui berbagai informasi baik terkait jangka waktu pengembalian, bunga pinjaman, perjanjian, serta risiko yang harus ditanggung ketika terjadi hal-hal yang tidak diinginkan. Kondisi tersebut dapat menimbulkan kecemasan seseorang terhadap situasi di masa mendatang hingga mampu menghilangkan rasa kesenangannya (Rusdini, 2021). Debt memiliki pengaruh terhadap kepuasan keuangan seseorang (Long et al., 2016). Hasil tersebut sejalan dengan penelitian dari Aboagye \& Jung (2018). Namun hasil berbeda ditunjukkan oleh penelitian Rusdini (2021) bahwa debt tidak terbukti berpengaruh terhadap financial satisfaction.

H2: Debt berpengaruh terhadap financial satisfaction pada karyawan. 
Subjective well-being theory juga dapat digunakan untuk menjelaskan pengaruh antara gender differences terhadap financial satisfaction (Wahab et al., 2019). Faktor demografi yang mampu memengaruhi kesejahteraan subjektif seseorang antara lain, jenis kelamin, pernikahan, dan pendapatan. Menurut Handi \& Mahastanti (2012), perbedaan gender yaitu suatu karakteristik dalam berperilaku yang membedakan antara laki-laki dan perempuan. Penelitian yang dilakukan oleh Sina (2013) mengungkapkan bahwa gender differences memiliki pengaruh terhadap financial satisfaction. Namun hasil tersebut berbeda dengan penelitian Wahab et al. (2019) yang menjelaskan bahwa gender differences tidak berpengaruh terhadap financial satisfaction.

H3: Gender differences berpengaruh terhadap financial satisfaction pada karyawan.

Pengaruh financial literacy terhadap financial satisfaction dalam penelitian ini dilandasi oleh theory of planned behavior (Rusdini, 2021). Perilaku seseorang didasari oleh niat dan tujuan pribadinya, salah satu faktor yang dapat memengaruhi perilaku seseorang adalah faktor informasi (Ajzen, 2005). Penelitian yang dilakukan oleh Nugraha et al. (2020) mengungkapkan bahwa financial literacy memiliki pengaruh terhadap financial satisfaction. Hasil penelitian tersebut sejalan dengan Prabowo \& Asandimitra (2021), Candra \& Memarista (2015), Yulinar et al., (2020), dan Adiputra (2021). Namun Amelia \& Isbanah (2021), Mukhafi (2020), dan Rusdini (2021) menunjukkan hasil yang berbeda dalam penelitiannya di mana financial literacy tidak memiliki pengaruh terhadap financial satisfaction.

H4: Financial literacy berpengaruh terhadap financial satisfaction pada karyawan.

Theory of planned behavior juga mendasari pengaruh financial attitude terhadap financial satisfaction dalam penelitian ini (Mukhafi, 2020). Menurut Kautsar \& Asandimitra (2019), financial attitude memiliki hubungan dengan sebuah pendapat, pola pikir individu, serta evaluasi yang dilakukan terkait masalah keuangan yang terwujud melalui sikap. Menurut Darmawan \& Pamungkas (2019), financial attitude memiliki pengaruh positif terhadap financial satisfaction. Hasil tersebut sejalan dengan penelitian dari Candra \& Memarista (2015) dan Adiputra (2021). Sedangkan penelitian Mukhafi (2020) dan Prabowo \& Asandimitra (2021) mendapatkan hasil berbeda yaitu financial attitude tidak berpengaruh terhadap financial satisfaction.

H5: Financial attitude berpengaruh terhadap financial satisfaction pada karyawan.

Berdasarkan pemaparan hipotesis di atas, maka model analisis penelitian dapat dilihat pada Gambar 1.

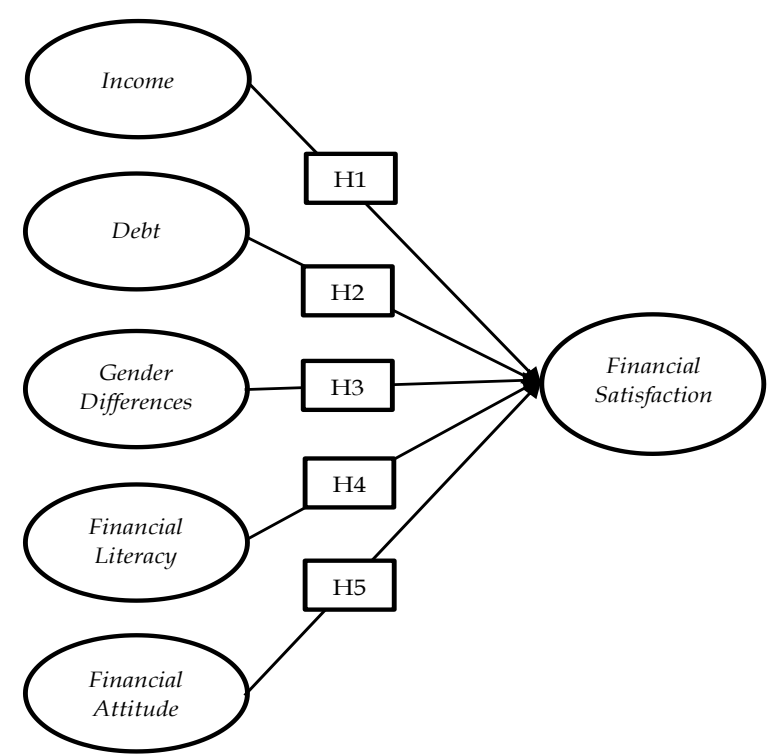

Gambar 1. MODEL PENELITIAN 
Ucik Nurul Hidayati Siswoyo \& Nadia Asandimitra. Pengaruh Income, Debt, Gender Differences, Financial Literacy, dan Financial Attitude terhadap Financial Satisfaction

\section{METODE PENELITIAN}

Jenis penelitian yang digunakan termasuk ke dalam jenis penelitian konklusif yang bersifat kausalitas. Variabel dependen dalam penelitian ini yaitu financial satisfaction, sedangkan variabel independen antara lain income, debt, gender differences, financial literacy, dan financial attitude. Data yang digunakan adalah jenis data kuantitatif, bersumber dari data primer yang diperoleh dari hasil kuesioner yang disebar secara online. Populasi dalam penelitian ini adalah karyawan di Kabupaten Sidoarjo. Dalam pengambilan sampel penelitian menggunakan teknik purposive sampling dan snowball sampling. Kriteria sampel yang dipilih adalah masyarakat Kabupaten Sidoarjo yang bekerja sebagai buruh/karyawan/pegawai di Badan Usaha Milik Negara (BUMN) atau Badan Usaha Milik Swasta (BUMS) yang ada di wilayah Kabupaten Sidoarjo. Kuesioner penelitian tersebar pada seluruh Kecamatan yang berada di Kabupaten Sidoarjo, yaitu meliputi Balongbendo, Buduran, Candi, Gedangan, Jabon, Krembung, Krian, Porong, Prambon, Sedati, Sidoarjo, Sukodono, Taman, Tanggulangin, Tarik, Tulangan, Waru, dan Wonoayu. Data yang terkumpul berjumlah 305 responden, namun terdapat 7 responden yang tidak memenuhi kriteria tempat tinggal. Sehingga hanya 298 data yang dapat digunakan untuk uji outlier, hasilnya terdapat 66 data outlier maka hanya 232 data yang dapat digunakan untuk uji selanjutnya. Jawaban responden diukur menggunakan skala likert, dengan menggunakan skor 1 sampai 4. Teknik analisis data yang digunakan yaitu Structural Equation Model (SEM) dengan program AMOS versi 24.

\section{HASIL DAN PEMBAHASAN}

\section{Karakteristik Responden}

Karakteristik yang dimiliki responden dalam penelitian ini terdiri dari laki-laki sebanyak 150 atau $50,3 \%$ dan perempuan sebanyak 148 atau $49,7 \%$ dengan berbagai golongan usia yaitu usia 15-24 tahun sebanyak 130 (43,6\%), usia 25-34 tahun sebanyak 99 (33,2\%), usia 35-44 tahun sebanyak 58 (19,5\%), dan sebanyak $11(3,7 \%)$ responden berusia 45 tahun ke atas. Pendidikan terakhir responden didominasi oleh lulusan SMA berjumlah 113 (37,9\%) dan S1 berjumlah 112 (37,5\%). Terdapat delapan belas kecamatan pada Kabupaten Sidoarjo, di mana terdapat $7(2,3 \%)$ responden yang tinggal di Balongbendo, Buduran sebanyak 6 (2\%), Candi sebanyak 11 (3,7\%), Gedangan, Jabon, Krian, Prambon, Taman mendapatkan hasil yang sama yaitu sebanyak 8 (2,7\%), Krembung sebanyak 82 (27,5\%), Porong sebanyak 24 (8,1\%), Sedati sebanyak 13 (4,4\%), Kecamatan Sidoarjo sebanyak 25 $(8,4 \%)$, Sukodono dan Tanggulangin juga mendapatkan hasil yang sama yaitu $14(4,7 \%)$, Taman dan Wonoayu juga sama yaitu 9 (3\%), Tarik sebanyak $10(3,4 \%)$, Tulangan sebanyak 20 (6,7\%), dan Waru sebanyak $23(7,7 \%)$ responden. Responden yang bekerja sebagai pegawai di BUMN (Badan Usaha Milik Negara) sebanyak 46,3\% atau 138 responden, sedangkan yang menjadi pegawai BUMS (Badan Usaha Milik Swasta) sebanyak 53,7\% atau 160 responden, dengan didominasi oleh responden yang berpendapatan $>$ Rp3.500.000 per bulan (golongan sangat tinggi) sebanyak 177 atau 59\% responden.

\section{Uji Outlier}

Melihat multivariate outlier dapat dilakukan dengan memerhatikan nilai pada mahalanobis distance. Jika terdapat data yang mempunyai nilai p2 $<0,001$ maka data tersebut merupakan data yang outlier. Setelah dilakukan uji, terdapat 66 data outlier sehingga harus dieliminasi. Data tersebut merupakan data responden dengan nomor $7,214,85,78,70,271,27,117,192,81,154,69,61,200,84,82,222,15$, $33,8,247,41,56,23,121,38,91,79,31,14,3,76,39,107,11,118,48,253,102,5,6,127,169,168$, 4, 74, 113, 290, 16, 2, 95, 191, 157, 156, 243, 83, 132, 241, 88, 116, 202, 165, 142, 181, 100, dan 163. Maka data yang dapat digunakan untuk uji berikutnya adalah 232 dari 298 data responden.

\section{Uji Normalitas}

Uji normalitas dapat dilihat pada assesment of normality, suatu data dapat dikatakan normal jika nilai critical ratio berada diantara $-2,58$ sampai dengan 2,58. Setelah dilakukan uji, diketahui bahwa DB 1 , DB 5, DB 6, dan DB 7 mempunyai nilai lebih dari $\pm 2,58$ dan dapat dinyatakan data tidak terdistribusi normal, sehingga harus dihapus. Sedangkan data item selain yang telah disebutkan sudah terdistribusi 
normal yaitu FS 1, FS 2, FS 3, FS 4, FS 5, FS 6, FS 7, IC 1, IC 2, DB 2, DB 3, DB 4, DB 8, DB 9, GD 1, GD 2, GD 3, FL 1, FL 2, FL 3, FL 4, FA 1, FA 2, FA 3, FA 4, FA 5, dan FA 6.

\section{Uji Validitas}

Uji validitas dilakukan dengan melihat hasil uji Variance Extraced dan discriminant validity. Teknik pertama yaitu dengan melakukan uji Varians Extraced (AVE) antar indikator suatu set konstruk yang merupakan ringkasan indikator konvergen dengan syarat AVE yaitu $\geq 0,50$. Nilai AVE pada varibel income dan financial literacy dalam penelitian ini yaitu lebih dari 0,5 sehingga indikator-indikator untuk variabel tersebut dapat dinyatakan valid. Sedangkan nilai AVE pada variabel financial satisfaction, debt, gender differences, dan financial attitude berada pada angka 0,4 sampai 0,5 yang artinya indikatorindikator untuk variabel tersebut belum dapat dinyatakan valid. Teknik kedua yaitu dengan menguji discriminant validity (sesama variabel eksogen) untuk mengukur seberapa jauh suatu konstruk atau indikator benar-benar berbeda dengan indikator lainnya. Syaratnya adalah nilai akar kuadrat dari AVE lebih tinggi dari nilai correlation antar variabel laten. Nilai akar kuadrat AVE semua variabel lebih tinggi daripada nilai korelasi antar indikator. Sehingga indikator-indikator dalam penelitian ini dinyatakan valid.

\section{Uji Reliabilitas}

Uji reliabilitas dilakukan dengan melihat nilai Construct Reliability $(C R)$. Syarat reliabilitas yang baik adalah jika nilai $\mathrm{CR} \geq 0,70$. Nilai $\mathrm{CR}$ pada variabel financial satisfaction, income, financial literacy, dan financial attitude dalam penelitian ini lebih dari 0,7 sehingga indikator-indikator dalam penelitian ini dinyatakan reliabel. Nilai CR pada variabel debt berada pada angka 0,6 sehingga indikator untuk variabel ini masih dapat dikatakan reliabel, sedangkan nilai CR pada variabel gender differences dibawah 0,6 sehingga indikator-indikator untuk variabel ini tidak dapat dinyatakan reliabel atau handal maka harus dilakukan eliminasi.

\section{Uji Kelayakan Model}

Uji kelayakan model dapat dilakukan dengan menggunakan uji Goodness of Fit dengan menggunakan kriteria chi-square, signifikansi probability, GFI, CMIN/DF, NFI, AGFI, RMSEA, dan TLI. Pada pengujian pertama model belum dapat dikatakan baik karena kriteria signifikansi probability < 0,05. Maka perlu dilakukan modification indices dengan melihat bersarnya nilai correlation error, yaitu error dengan nilai terbesar akan dihubungkan serta melakukan eliminasi pada indikator-indikator yang tidak valid.

Tabel 1.

UJI KELAYAKAN MODEL

\begin{tabular}{lccc}
\hline \multicolumn{1}{c}{ Goodness of Fit } & Cut of Value & Nilai & Keterangan \\
\hline Chi-square & Diharapkan kecil & 118,181 & Baik \\
Signifikansi Probability & $\geq 0,05$ & 0,237 & Baik \\
GFI (Goodness of Fit Index) & $\geq 0,90$ & 0,947 & Baik \\
CMIN/DF & $\leq 2,00$ & 1,094 & Baik \\
NFI (Normed Fit Index) & $\geq 0,90$ & 0,954 & Baik \\
AGFI & $\geq 0,90$ & 0,917 & Baik \\
RMSEA & $0,05-0,08$ & 0,020 & Marginal \\
TLI & $\geq 0,90$ & 0,994 & Baik \\
\hline
\end{tabular}

Sumber: Data diolah (2021)

Uji kelayakan model yang sudah dilakukan modifikasi dapat dilihat pada tabel 1 yang menunjukkan bahwa model penelitian sudah fit karena dari 8 kriteria hanya terdapat 1 kriteria yang memiliki hasil marginal. Di mana kriteria chi-square memiliki nilai 118,181 , signifikansi probability 0,237 , GFI 0,947, CMIN/DF 1,094, NFI 0,954, AGFI 0,917, RMSEA 0,020, dan TLI 0,994. Model diagram jalur yang sudah fit dapat dilihat pada Gambar 2. 
Ucik Nurul Hidayati Siswoyo \& Nadia Asandimitra. Pengaruh Income, Debt, Gender Differences, Financial Literacy, dan Financial Attitude terhadap Financial Satisfaction

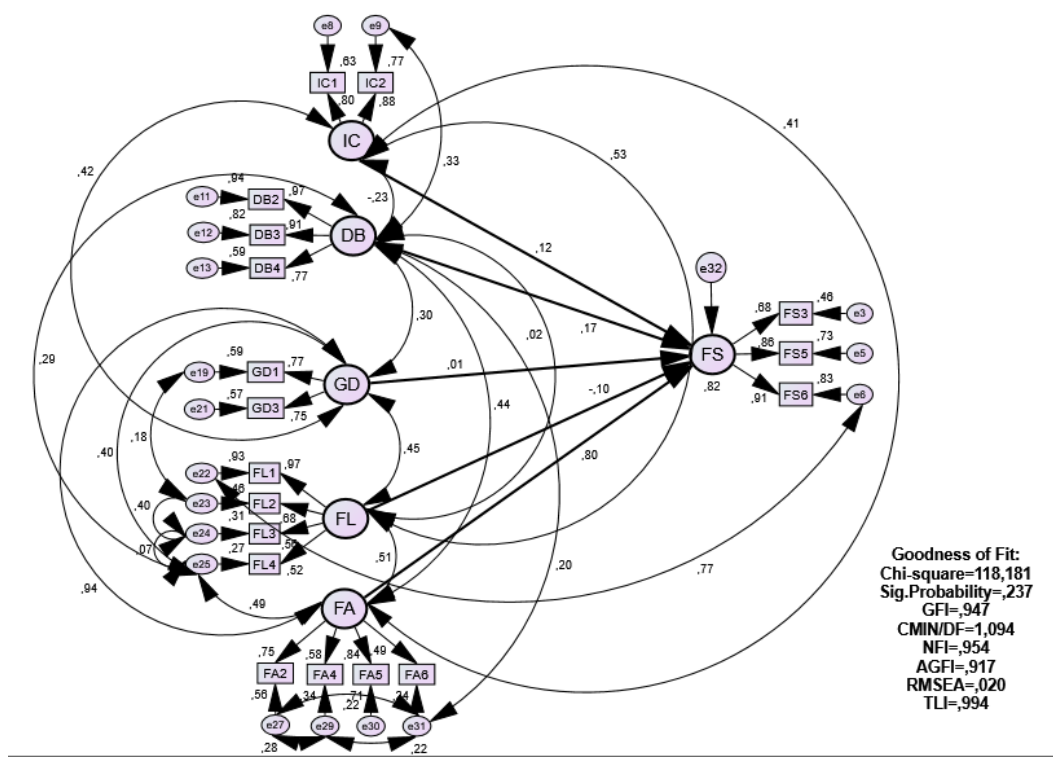

Sumber: Data diolah (2021)

Gambar 2. MODEL DIAGRAM JALUR

\section{Uji Hipotesis}

Kriteria untuk melakukan uji hipotesis adalah jika pengaruh antar variabel mempunyai CR hitung $\geq$ 2,00 maka dapat dikatakan bahwa pengaruh tersebut signifikan. Jika nilai $\mathrm{P} \leq 0,05$ maka dapat dikatakan bahwa pengaruh tersebut signifikan atau terdapat pengaruh antara variabel eksogen terhadap variabel endogen. Berdasarkan tabel 2 dapat diketahui bahwa H1 ditolak karena nilai P sebesar 0,104 $(>0,05)$ dan nilai CR 1,626 $(<2,00), \mathrm{H} 2$ diterima karena memiliki nilai $\mathrm{P}$ sebesar $0,039(<0,05)$ dan nilai CR 2,060 (>2,00), H3 ditolak karena nilai P sebesar 0,964 (>0,05) dan nilai CR 0,045 $(<2,00), \mathrm{H} 4$ ditolak karena nilai P sebesar $0,258(>0,05)$ dan nilai CR $-1,131(<2,00)$, dan $\mathrm{H} 5$ diterima karena memiliki nilai P sebesar 0,027 $(<0,05)$ dan nilai CR 2,207 $(>2,00)$.

Tabel 2.

\section{HASIL UJI HIPOTESIS}

\begin{tabular}{ccccc}
\hline Variabel & Estimate & S.E. & C.R. & P \\
\hline FS $\leftarrow$ IC &, 102 &, 063 & 1,626 &, 104 \\
FS $\leftarrow$ DB &, 081 &, 039 & 2,060 &, 039 \\
FS $\leftarrow$ GD &, 011 &, 246 &, 045 &, 964 \\
FS $\leftarrow$ FL &,- 076 &, 067 & $-1,131$ &, 258 \\
FS $\leftarrow$ FA &, 703 &, 319 & 2,207 &, 027 \\
\hline
\end{tabular}

Sumber: Data diolah (2021)

\section{Uji Determinasi}

Analisis Determinasi dilakukan untuk mengetahui seberapa besar kontribusi variabel independen terhadap variabel dependen, atau mengukur seberapa jauh kemampuan model dalam menerangkan variabel dependennya yang dapat dilihat pada nilai squared multiple correlation. Nilai $r$-square atau nilai estimate pada variabel financial satisfaction sebesar 0,820, yang mengartikan bahwa pengaruh income, debt, gender differences, financial literacy, dan financial attitude terhadap financial satisfaction sebesar $82 \%$, sedangkan $18 \%$ dijelaskan oleh faktor di luar dari penelitian ini, seperti variabel hedonism lifestyle yang terbukti berpengaruh signifikan terhadap financial satisfaction, hasil ini termuat dalam penelitian yang dilakukan oleh Raprayogha \& Rusnawati (2020), lalu ada juga variabel financial afficacy yang terbukti berpengaruh positif terhadap financial satisfaction dalam penelitian Sina (2013), dan juga variabel locus of control yang terbukti berpengaruh signifikan terhadap financial satisfaction yang dijelaskan dalam penelitian Adiputra (2021) yang menjelaskan bahwa 
variabel-variabel tersebut merupakan faktor di luar dari penelitian ini yang terbukti dapat menjelaskan variabel financial satisfaction.

\section{Pengaruh Income terhadap Financial Satisfaction}

Berdasarkan hasil dari uji hipotesis menunjukkan bahwa variabel income tidak berpengaruh terhadap variabel financial satisfaction, sehingga dalam penelitian ini hipotesis ditolak. Hasil penelitian ini tidak sesuai dengan Subjective Well-Being Theory, di mana teori ini mendefinisikan bahwa pendapatan memberikan pengaruh yang cukup kuat terhadap subjective well-being (Diener et al., 2003). Pendapatan yang tinggi tidak selalu membuat seseorang merasa puas. Hal tersebut dapat dipengaruhi oleh berbagai faktor seperti kebutuhan yang terus meningkat, gaya hidup hedonisme, serta tanggungan yang harus dipenuhi setiap orang akan berbeda sehingga tingkat kepuasan keuangan setiap individu tidak sama. Hasil ini disebabkan karena berdasarkan kriteria secara deskriptif atas jawaban responden di mana tingkat pendapatan pada keseluruhan responden termasuk tinggi, sedangkan tingkat kepuasan keuangan berada dalam kondisi sedang. Berdasarkan hasil kuesioner yang telah dijawab oleh responden dalam penelitian ini, menandakan bahwa pendapatan yang besar tidak selalu membuat seseorang merasakan kepuasan keuangan, kondisi tersebut dapat dipengaruh oleh berbagai faktor seperti kebutuhan dan gaya hidup yang semakin meningkat akan tetapi pendapatan tidak bertambah, semakin dewasa seseorang maka akan semakin banyak tanggungan yang harus dipenuhi. Implikasi praktik dalam penelitian ini yaitu pendapatan yang diterima akan berbeda untuk setiap orang, hal tersebut juga sejalan dengan perbedaan kebutuhan dan keinginan serta tanggungan yang dimiliki oleh setiap individu. Maka buruh/karyawan/pegawai sebaiknya dapat mengelola keuangannya dengan baik melaui beberapa cara, seperti mengalokasikannya pada beberapa produk keuangan contohnya berinvestasi ataupun menyimpan uangnya sebagai tindakan berjaga-jaga, karena pendapatan yang tinggi tidak dapat menjamin individu dapat merasakan kesejahteraan hingga mencapai kepuasan keuangan pribadi jika manajemen keuangannya tidak tertata dengan baik. Hasil penelitian ini sejalan dengan penelitian Amelia \& Isbanah (2021) dan Rusdini (2021) yang menunjukkan hasil bahwa income tidak berpengaruh terhadap financial satisfaction.

\section{Pengaruh Debt terhadap Financial Satisfaction}

Uji hipotesis yang telah dilakukan menyatakan bahwa variabel debt berpengaruh terhadap variabel financial satisfaction, sehingga dalam penelitian ini hipotesis diterima. Hasil penelitian ini sesuai dengan Subjective Well-Being Theory di mana hutang merupakan tanggungan berupa kewajiban terhadap pihak lain yang belum terselesaikan. Seseorang yang berhutang tentunya harus mengetahui berbagai informasi baik terkait jangka waktu pengembalian, bunga pinjaman, perjanjian, serta risiko yang harus ditanggung ketika terjadi hal-hal yang tidak diinginkan Rusdini (2021). Diketahui bahwa seseorang dapat mencapai tingkat kepuasannya tersebut bergantung pada kegiatan emosionalitas yang telah dialami. Hasil ini terjadi berdasarkan kriteria secara deskriptif atas jawaban responden, di mana tingkat pendapatan pada keseluruhan responden termasuk tinggi, sedangkan tingkat hutang berada dalam kondisi cukup baik atau sedang. Implikasi praktik dalam penelitian ini yaitu tinggi rendahnya pendapatan seseorang belum tentu efektif dan berimplikasi pada terpenuhinya kebutuhan sehari-hari karena kebutuhan setiap individu akan berbeda, hal ini dapat ditinjau dari seberapa banyak tanggungan serta kewajiban yang harus dipenuhi. Sehingga berdasarkan jawaban reponden pada kuesioner, menunjukkan bahwa hutang dapat memenuhi kebutuhan darurat mereka. Maka buruh/karyawan/pegawai sebaiknya dapat mengelola hutang yang dimiliki secara tepat dan sesuai tujuan, sehingga dapat menciptakan kesejahteraan hidup orang yang berhutang hingga mampu mencapai kepuasan keuangan. Hasil penelitian ini sejalan dengan penelitian Long et al., (2016) dan Aboagye \& Jung (2018) di mana debt memiliki pengaruh terhadap kepuasan keuangan seseorang.

\section{Pengaruh Gender Differences terhadap Financial Satisfaction}

Berdasarkan hasil uji hipotesis, variabel gender differences tidak berpengaruh terhadap variabel financial satisfaction, sehingga dalam penelitian ini hipotesis ditolak. Hal ini tidak sesuai dengan Subjective Well-Being Theory yang menjelaskan bahwa perbedaan tingkat kepuasan setiap orang dipengaruhi oleh tingkat kesejahteraan yang berdasarkan afektif dan kognitif, kegiatan emosional yang terjadi, dan proses adanya informasi emosionalitas (Diener et al., 2003). Faktor demografi yang mampu 
Ucik Nurul Hidayati Siswoyo \& Nadia Asandimitra. Pengaruh Income, Debt, Gender Differences, Financial Literacy, dan Financial Attitude terhadap Financial Satisfaction

memengaruhi kesejahteraan subjektif seseorang antara lain, jenis kelamin, pernikahan, dan pendapatan. Hipotesis penelitian ini ditolak karena berdasarkan hasil kuesioner dalam penelitian ini, di mana jumlah data responden antara laki-laki dan perempuan tidak jauh berbeda yaitu responden laki-laki sebanyak 150 atau 50,3\% sedangkan responden perempuan sebanyak 148 atau 49,7\%. Implikasi praktik dalam penelitian ini berdasarkan hasil kuesioner yaitu perbedaan karakteristik antara laki-laki dan perempuan tidak menunjukkan perbedaan hasil yang spesifik terhadap cara pengelolaan keuangannya, hal tersebut ditinjau dari beberapa faktor seperti kegiatan evaluasi atas segala sesuatu yang telah dilakukan, kecemasan keuangan yang dihadapai, serta kegiatan berbagi terhadap sesama, di mana faktor-faktor tersebut menunjukkan tidak adanya perbedaan cara mengelola keuangan antara laki-laki dan perempuan untuk mencapai kepuasan keuangannya. Maka buruh/karyawan/pegawai baik laki-laki ataupun perempuan sebaiknya selalu memerhatikan tindakan keuangannya dengan melakukan evaluasi tindakan, mengontrol kecemasan, serta kedermawanan akan uang yang dimiliki agar dapat mencapai kepuasan keuangan secara pribadi. Hasil penelitian ini sejalan dengan penelitian terdahulu yang dilakukan oleh Wahab et al. (2019) yang mengungkapkan bahwa gender differences tidak berpengaruh terhadap financial satisfaction.

\section{Pengaruh Financial Literacy terhadap Financial Satisfaction}

Berdasarkan hasil uji hipotesis, variabel financial literacy tidak berpengaruh terhadap variabel financial satisfaction, sehingga hipotesis dalam penelitian ini ditolak. Hal ini tidak sejalan dengan Theory of Planned Behavior Teori ini menjelaskan bahwa perilaku seseorang didasari oleh niat dan tujuan pribadinya. Salah satu faktor yang dapat memengaruhi perilaku seseorang adalah faktor informasi (Ajzen, 2005). Financial literacy dapat digolongkan dalam berbagai jenis informasi berupa pengetahuan, di mana informasi tersebut dapat berupa sebuah pengetahuan, pemahaman, pencarian, serta pengalaman yang berkaitan dengan keuangan (Yap et al., 2018). Informasi yang diperoleh dan dimiliki tidak membentuk serta menentukan bagaimana seseorang dalam menentukan keputusan keuangan. Seseorang akan mampu mencapai kepuasan keuangan jika dapat membuat keputusan keuangan secara tepat sesuai dengan tujuan yang telah ditentukan (Candra \& Memarista, 2015). Hipotesis penelitian ini ditolak karena berdasarkan pada kriteria secara deskriptif atas jawaban responden, di mana tingkat financial literacy pada keseluruhan responden termasuk tinggi tetapi tingkat financial satisfaction dalam kondisi sedang. Implikasi praktik dalam penelitian ini yaitu tinggi atau rendahnya tingkat literasi keuangan seseorang baik berupa pengetahuan, pemahaman terkait keuangan pribadi, simpanan atau pinjaman, asuransi, dan investasi, serta pencarian atau pengalaman yang berkaitan dengan keuangan belum tentu berimplikasi dalam memberikan perspektif atau pandangan terhadap penentuan keputusan keuangan untuk mencapai kepuasan keuangan pribadi. Sehingga penting dilakukan penindakan dari pemerintah untuk menciptakan program dan pembimbingan terhadap literasi keuangan karyawan di Kabupaten Sidoarjo. Selain itu, sebaiknya karyawan selalu meningkatkan literasi keuangan melalui informasi yang bisa didapatkan pada berbagai platform digital pada era modern saat ini. Hasil penelitian ini sejalan dengan Amelia \& Isbanah (2021); Mukhafi (2020); dan Rusdini (2021) di mana financial literacy tidak memiliki pengaruh terhadap financial satisfaction.

\section{Pengaruh Financial Attitude terhadap Financial Satisfaction}

Berdasarkan hasil uji hipotesis, variabel financial attitude berpengaruh terhadap variabel financial satisfaction, sehingga dalam penelitian ini hipotesis diterima. Hal ini sesuai dengan Theory of Planned Behavior, di mana dalam teori ini terdapat tiga jenis pertimbangan dalam berperilaku yaitu attitudes toward behavior, subjective norms, dan perceived behavioral control (Ajzen, 1991). Salah satu faktor yang menjadi pertimbangan seseorang dalam berperilaku adalah sikap. Sikap perilaku didefinisikan sebagai suatu keyakinan seseorang terhadap sikap yang menunjukkan bahwa seseorang akan melakukan penilaian secara subjektif kepada dirinya. Hipotesis penelitian ini diterima karena berdasarkan kriteria secara deskriptif atas jawaban responden, di mana tingkat financial attitude pada keseluruhan responden termasuk tinggi. Implikasi praktik dalam penelitian ini yaitu sikap positif ataupun negatif seseorang akan keuangannya berimplikasi dalam perspektif atau pandangan terhadap penentuan keputusan keuangan untuk mencapai kepuasan keuangannya. Sehingga sikap keuangan dapat diimplementasikan dan cukup untuk mempresentasikan ketepatan keputusan keuangan untuk mencapai kepuasan keuangan yang dimiliki responden dalam penelitian ini. Financial attitude berperan penting untuk menentukan 
keberhasilan atau kegagalan perilaku keuangan individu. Tingginya sikap keuangan karyawan dapat menentukan tingginya kesadaran dalam bertanggungjawab atas pengeluaran keuangannya, sehingga akan menimbulkan dampak positif pada perilaku manajemen keuangan. Karyawan yang memiliki sikap keuangan yang baik mampu menahan diri dalam berperilaku konsumtif serta memiliki kendali yang baik pada perilaku keuangannya, sehingga dapat menunjang seseorang untuk merasakan kepuasan keuangan pribadi. Hasil penelitian ini sejalan dengan penelitian Darmawan \& Pamungkas (2019), Candra \& Memarista (2015) dan Adiputra (2021), yang menunjukkan bahwa financial attitude memiliki pengaruh yang positif terhadap financial satisfaction.

\section{KESIMPULAN}

Berdasarkan pembahasan di atas, maka dapat disimpulkan income tidak berpengaruh terhadap financial satisfaction, karena pendapatan yang besar tidak selalu membuat seseorang merasakan kepuasan keuangan, kondisi tersebut dapat dipengaruh oleh berbagai faktor seperti kebutuhan dan gaya hidup yang semakin meningkat akan tetapi pendapatan tidak bertambah, semakin dewasa seseorang maka akan semakin banyak tanggungan yang harus dipenuhi. Debt berpengaruh signifikan terhadap financial satisfaction, karena tinggi rendahnya pendapatan seseorang belum tentu efektif dan berimplikasi pada terpenuhinya kebutuhan sehari-hari karena kebutuhan setiap individu akan berbeda, hal ini dapat ditinjau dari seberapa banyak tanggungan serta kewajiban yang harus dipenuhi. Gender differences tidak berpengaruh terhadap financial satisfaction, karena tidak adanya perbedaan cara mengelola keuangan antara laki-laki dan perempuan untuk mencapai kepuasan keuangannya. Financial literacy tidak berpengaruh terhadap financial satisfaction, karena tinggi atau rendahnya tingkat literasi keuangan seseorang belum tentu berimplikasi dalam memberikan perspektif atau pandangan terhadap penentuan keputusan keuangan untuk mencapai kepuasan keuangan pribadi. Financial attitude berpengaruh signifikan terhadap financial satisfaction, karena sikap positif ataupun negatif seseorang akan keuangannya berimplikasi dalam perspektif atau pandangan terhadap penentuan keputusan keuangan untuk mencapai kepuasan keuangan pribadi.

Penelitian ini memiliki keterbatasan antara lain sampel yang diamati cukup sedikit yaitu karyawan yang bekerja di Badan Usaha Milik Negara (BUMN) ataupun Badan Usaha Milik Swasta (BUMS) serta wilayah penelitian yang cukup sempit yakni hanya bersumber dari Kabupaten Sidoarja, yang meliputi Balongbendo, Buduran, Candi, Gedangan, Jabon, Krembung, Krian, Porong, Prambon, Sedati, Sidoarjo, Sukodono, Taman, Tanggulangin, Tarik, Tulangan, Waru, dan Wonoayu. Karyawan khususnya yang bekerja di BUMN (Badan Usaha Milik Negara) ataupun BUMS (Badan Usaha Milik Swasta) di Kabupaten Sidoarjo sebaiknya selalu bertindak dan bersikap baik dalam hal keuangan, karena sikap terhadap keuangan berperan penting untuk menentukan keberhasilan atau kegagalan perilaku keuangan individu. Sikap keuangan yang baik dapat dilakukan dengan cara mengendalikan obsesi atas segala sesuatu, memiliki kekuatan untuk mengontrol tindakan, melakukan usaha sebaik mungkin untuk apa yang dibutuhkan, mengendalikan sikap ketika mengalami ketidakcukupan, dan mampu mengelola tabungan yang dimiliki dengan baik. Sehingga upah/gaji yang dikelola secara bijak akan menunjang seseorang untuk dapat merasakan kesejahteraan keuangan dan mampu meningkatkan kepuasan keuangan pribadi. Perusahaan penyerap tenaga kerja hendaknya bersedia untuk mewadahi para pekerja dengan cara memberikan program ataupun pelatihan untuk meningkatkan kesadaran akan sikap keuangan yang baik dan benar. Dalam menyukseskan kegiatan tersebut, perusahaan dapat melakukan kerjasama dengan pihak terkait untuk memberikan informasi tentang konsep dan produk keuangan, sehingga karyawan mampu meningkatkan kesadaran untuk mengelola keuangannya secara bijak. Penelitian selanjutnya disarankan untuk melakukan penelitian ulang tentang kepuasan keuangan dengan menggunakan variabel-variabel di luar dari penelitian ini, seperti variabel hedonism lifestyle, financial afficacy, dan locus of control. Variabel-variabel tersebut termuat dalam penelitian terdahulu dan terbukti dapat menjelaskan variabel financial satisfaction.

\section{DAFTAR PUSTAKA}

Aboagye, J., \& Jung, J. Y. (2018). Debt Holding, Financial Behavior, and Financial Satisfaction. 
Ucik Nurul Hidayati Siswoyo \& Nadia Asandimitra. Pengaruh Income, Debt, Gender Differences, Financial Literacy, dan Financial Attitude terhadap Financial Satisfaction

Journal of Financial Counseling and Planning, 29(2), 208-218. https://doi.org/10.1891/10523073.29.2.208

Adiputra, I. G. (2021). The Influence of Financial Literacy, Financial Attitude and Locus of Control on Financial Satisfaction: Evidence From the Community in Jakarta. KnE Social Sciences, 2021, 636-654. https://doi.org/10.18502/kss.v5i5.8848

Ajzen, I. (1991). The Theory of Planned Behavior. Organizational Behavior and Human Decision Processes, 50, 179-211. https://doi.org/10.1016/0749-5978(91)90020-T

Ajzen, I. (2002). Perceived Behavioral Control, Self-Efficacy, Locus of Control, and The Theory of Planned Behavior. Journal of Applied Social Psychology, 32(4), 665-683. https://doi.org/10.1111/j.1559-1816.2002.tb00236.x

Ajzen, I. (2005). Attitudes, Personallity and Behavior (Second Edi). New York: British Library.

Amelia, M., \& Isbanah, Y. (2021). Analisis Faktor-Faktor yang Memengaruhi Financial Satisfaction Pengguna E-Wallet. Jurnal Ilmu Manajemen (JIM), 9(2), 426-437. https://doi.org/10.26740/jim.v9n2.p426-437

Candra, J. W., \& Memarista, G. (2015). Faktor-faktor yang Mempengaruhi Financial Satisfaction pada Mahasiswa Universitas Kristen Petra. Finesta, 3(2), 1-6.

Chen, H., \& Volpe, R. P. (1998). An Analysis of Personal Financial Literacy Among College Students. Financial Services Review, 7(2), 107-128. https://doi.org/10.1016/S1057-0810(99)80006-7

Darmawan, D., \& Pamungkas, A. S. (2019). Pengaruh Financial Attitude, Financial Behavior, dan Financial Knowledge terhadap Financial Satisfaction. Jurnal Manajerial Dan Kewirausahaan, $1(2), 172-181$.

Diener, E., Oishi, S., \& Lucas, R. E. (2003). Personality, Culture, and Subjective Well-Being: Emotional and Cognitive Evaluations of Life. Annual Review of Psychology, 54, 403-425. https://doi.org/10.1146/annurev.psych.54.101601.145056

Handi, A. K., \& Mahastanti, L. A. (2012). Perilaku Penggunaan Uang: Apakah Berbeda untuk Jenis Kelamin dan Kesulitan Keuangan. Seminar Keuangan Dan Call for Papers, 1-18. http://eprints.unisbank.ac.id/257/

Hasibuan, B. K., Lubis, Y. M., \& HR, W. A. (2018). Financial Literacy and Financial Behavior as a Measure of Financial Satisfaction. Proceedings of the 1st Economics and Business International Conference 2017 (EBIC 2017), 46, 503-507. https://doi.org/10.2991/ebic-17.2018.79

Herdjiono, I., \& Damanik, L. A. (2016). Pengaruh Financial Attitude,Financial Knowledge, Parental Income terhadap Financial Management Behavior. Jurnal Manajemen Teori Dan Terapan, 9(3), 226-241. https://doi.org/10.20473/jmtt.v9i3.3077

Kautsar, A., \& Asandimitra, N. (2019). Financial Knowledge as Youth Preneur Success Factor. Journal of Social and Development Sciences, 10(2), 26-32. https://doi.org/10.1007/s11273-020-09706-3

Long, G. T., Viet, M. H., \& Diep, N. T. H. (2016). Gender Differences in Financial Sources and Perceived Financial Satisfaction Among Older People in Vietnam. Journal of Economics and Development, 18(2), 36-58. https://doi.org/10.33301/2016.18.02.03

Mukhafi, C. M. (2020). Faktor-faktor yang Memengaruhi Financial Satisfaction Buruh di Kota 
Surabaya. Jurnal Ilmu Manajemen (JIM), $\quad 8(4), \quad 1312-1324$. https://doi.org/10.26740/jim.v8n4.p1312-1324

Nugraha, D. F., Pratama, I. M., \& Kustiawan, M. (2020). Financial Satisfaction Increase: Effect of Income and Financial Literacy Factors (Study of MSMEs). Proceedings of the 3rd International Conference on Research of Educational Administration and Management (ICREAM 2019), 400, 320-322. https://doi.org/10.2991/assehr.k.200130.193

Prabowo, M. S., \& Asandimitra, N. (2021). Faktor yang Memengaruhi Financial Satisfaction Pengguna E-Commerce di Surabaya. Jurnal Ilmu Manajemen (JIM), 9(1), 28-41. https://doi.org/10.26740/jim.v9n1.p28-41

Rai, K., Dua, S., \& Yadav, M. (2019). Association of Financial Attitude, Financial Behaviour and Financial Knowledge Towards Financial Literacy: A Structural Equation Modeling Approach. FIIB Business Review, 8(1), 51-60. https://doi.org/10.1177/2319714519826651

Raprayogha, R., \& Rusnawati, R. D. A. P. (2020). Efek Mediasi Perilaku Keuangan Dan Dampak Kepuasan Keuangan Masyarakat Di Kota Makassar. ASSETS: Jurnal Ekonomi, Manajemen, Dan Akuntansi, 10(1), 62-82. https://doi.org/10.24252/assets.v10i2.14759

Rizal, J. G. (2021). Daftar Lengkap UMP 2021 di 34 Provinsi Indonesia: DKI Jakarta Tertinggi, DIY Terendah. Kompas.com. Retrieved October 09, 2021, from https://www.kompas.com/tren/read/2021/01/09

Rusdini, D. A. (2021). Faktor yang Memengaruhi Financial Satisfaction pada Masyarakat Kabupaten Pamekasan. Jurnal Ilmu Manajemen, 9(1), 182-190. https://doi.org/10.26740/jim.v9n1.p182190

Rusdini, D. A., Mulyaningsih, T. I. S., Ghaisani, I., \& Kautsar, A. (2020). Impact of Financial Knowledge, Socio-Demographics, and Debt on Financial Satisfaction of Kediri People. International Journal of Latest Engineering and Management Research (IJLEMR), 5(1), 06-09.

Safryani, U., Aziz, A., \& Triwahyuningtyas, N. (2020). Analisis Literasi Keuangan, Perilaku Keuangan, dan Pendapatan terhadap Keputusan Investasi. Jurnal Ilmiah Akuntansi Kesatuan, 8(3), 319-332. https://doi.org/10.37641/jiakes.v8i3.384

Sahi, S. K. (2013). Demographic and Socio-Economic Determinants of Financial Satisfaction: A Study of SEC-A Segment of Individual Investors in India. International Journal of Social Economics, 40(2), 127-150. https://doi.org/10.1108/03068291311283607

Sawitri, N. N. (2018). Behavior in Managing Revenue to Achieve Financial Satisfaction. Opcion, 34(86), 1274-1291.

Septiana, T. (2021). Daftar UMK Jawa Timur 2021: Kota Surabaya Tertinggi, Kabupaten Sampangan Terendah. Regional.kontan.co.id. Retrieved October 09, 2021, from https://regional.kontan.co.id/news/daftar-umk-jawa-timur-2021-kota-surabaya-tertinggikabupaten-sampangan-terendah

Sina, P. G. (2013). Financial Efficacy and Financial Satisfaction: Ditinjau dari Perbedaan Gender. Jurnal Manajemen Maranatha, 12(2), 173-184. https://doi.org/10.28932/jmm.v12i2.164

Wahab, A., Aprilla, I. R., \& Mulia, A. (2019). Determinan Kepuasan Keuangan Pelaku UMKM. ASSETS: Jurnal Ekonomi, Manajemen Dan Akuntansi, 9(2), 138-150. https://doi.org/10.24252/assets.v9i2.13127 
Ucik Nurul Hidayati Siswoyo \& Nadia Asandimitra. Pengaruh Income, Debt, Gender Differences, Financial Literacy, dan Financial Attitude terhadap Financial Satisfaction

Wijanarka, Hanung., Syafriza;, Maslim R., Dewi, Tiara R.,Junedi.,Amri, Auliak., Hardyanto, Esya.(2018). Metadata Sensus Ekonomi 2016 Lanjutan. Jakarta: Penerbit Badan Pusat Statistik.

Yap, R. J. C., Komalasari, F., \& Hadiansah, I. (2018). The Effect of Financial Literacy and Attitude on Financial Management Behavior and Satisfaction. International Journal of Administrative Science and Organization, 23(3), 139-146. https://doi.org/10.20476/jbb.v23i3.9175

Yulianingrum, A., Rianto, M. R., \& Handayani, M. (2021). Pengaruh Pengetahuan Keuangan, Pendapatan, dan Perilaku Keuangan terhadap Kepuasan Keuangan pada Tenaga Harian Lepas SATPOL PP di Kabupaten (X). Jurnal Ilmiah Akuntansi Dan Manajemen (JIAM), 17(1), 71-77. https://doi.org/10.31599/jiam.v17i1.582

Yulinar, B., * Y., \& Umrie, R. H. (2020). Literasi Keuangan dan Kepuasan Keuangan dengan Gender sebagai Moderasi: Studi pada Mahasiswa di Kota Palembang. Jurnal Manajemen Dan Bisnis Equilibrium, 6(1), 1-16. https://doi.org/10.47329/jurnal_mbe.v6i1.424 